O. N. Ragozin, Ye. Yu. Shalamova, N. A. Ilyushchenko, O. V. Ragozina, I. A. Shevnin, D. V. Surinov

\title{
SEX AND AGE CHARACTERISTICS OF DAILY ACTIVITYOF DISTANCE LEARNING STUDENTS IN NORTHERN CLIMATE
}

О. Н. Рагозин, Е. Ю. Шаламова, Н. А. Ильющенко, О. В. Рагозина, И. А. Шевнин, Д. В. Суринов

\section{ПОЛОВОЗРАСТНЫЕ ОСОБЕННОСТИ СУТОЧНОЙ АКТИВНОСТИ СТУДЕНТОВ НА СЕВЕРЕ ПРИ ДИСТАНЦИОННОМ ОБУЧЕНИИ}

\begin{abstract}
The purpose of the work is to study the time preferences of students performing daily tasks during distance learning and to determine if such preferences depend on sex and the year of study. In the absence of social regulation, the daytime and nighttime activity of students corresponded to the distribution of chronotypesthat typifies a northern region, with arrhythmic and evening types prevailingbut the morning biorhythmic stereotype having a minimal representation. With no 'master timer' in distance learning, students demonstrated pronounced sex differences in the daily dynamics of performance. Young femaleshad maximum performanceduring the day and minimum performanceat night, which corresponds to the most common type. Young males were observed to have several ascents in their performance during the 24-hour period. First-year and second-year students' learning behavior was less synchronized with the day-night cycle. The wavelet analysis found insignificant four to five hourrhythmic fluctuations thatoccurred in the evening hours, during the period of students' high educational performance.
\end{abstract}

Key words: performance rhythms; distance learning; north; wavelet-analysis.
Аннотация. Цель работы - исследовать временные предпочтения выполнения ежедневных заданий студентами при дистанционном обучении с учетом пола и курса обучения. Присутствие дневной и вечерней активности студентов при отсутствии социальной регламентации соответствует распределению хронотипов, характерному для северного региона, где превалируют аритмичный и вечерний типы при минимальном представительстве утреннего биоритмологического стереотипа. При отсутствии социального задатчика времени при дистанционном обучении у студентов наблюдаются выраженные межполовые различия суточной динамики работоспособности. Девушки демонстрируют классический тип с максимальными значениями днем и минимальными ночью, у юношей наблюдается кривая с несколькими подъемами активности. Студенты младших курсов менее синхронизированы с циклом день-ночь. При проведении вейвлет-анализа обнаруживаются незначимые ритмические колебания с периодом 4-5 часов, которые возникают в вечерние часы, в период высокой учебной продуктивности студентов. Ключевые слова: ритмы работоспособности; дистанционное обучение; север; вайвлет-анализ.

\begin{abstract}
About the authors: Ragozin Oleg Nikolayevich, ORCID: 0000-0002-5318-9623, Dr. habil., Khanty-Mansiysk State Medical Academy, Khanty-Mansiysk, Russia, oragozin@mail.ru; Shalamova Yelena Yurievna, ORCID: 00000001-5201-4496, Ph.D., Khanty-Mansiysk State Medical Academy, Khanty-Mansiysk, Russia, selenzik@mail.ru; Ilyushchenko Natalia Alexandrovna, ORCID: 0000-0002-1261-3352, Ph.D., Khanty-Mansiysk State Medical Academy, Khanty-Mansiysk, Russia, iluyshenko@yandex.ru; Ragozina Olga Vasilyevna, ORCID: 0000-0002-40517819, Ph.D., Khanty-Mansiysk State Medical Academy, Khanty-Mansiysk, Russia, olga1ragozina111@gmail.com; Shevnin Igor Nikolayevich, ORCID: 0000-0003-1772-1026, Khanty-Mansiysk State Medical Academy, KhantyMansiysk, Russia, igor_shevnin@mail.ru; Surinov Daniil Vladimirovich, ORCID: 0000-0001-5822-8575, KhantyMansiysk State Medical Academy, Khanty-Mansiysk, Russia, surinof.daniil@yandex.ru.
\end{abstract}

Сведения об авторах: Рагозин Олег Николаевич, ORCID: 0000-0002-5318-9623, д-р мед. наук, ХантыМансийская государственная медицинская академия, г. Ханты-Мансийск, Россия, oragozin@mail.ru; Шаламова Елена Юрьевна, ORCID: 0000-0001-5201-4496, канд. биол. наук, Ханты-Мансийская государственная медицинская академия, г. Ханты-Мансийск, Россия, selenzik@mail.ru; Ильющенко Наталья Александровна, ORCID: 0000-0002-1261-3352, канд. мед наук, Ханты-Мансийская государственная медицинская академия, г. Ханты-Мансийск, Россия, iluyshenko@yandex.ru; Рагозина Ольга Васильевна, ORCID: 0000-0002-40517819, канд. мед наук, Ханты-Мансийская государственная медицинская академия, г. Ханты-Мансийск, Россия, olga1ragozina111@gmail.com; Шевнин Игорь Андреевич, ORCID: 0000-0003-1772-1026, ХантыМансийская государственная медицинская академия, г. Ханты-Мансийск, Россия, igor_shevnin@mail.ru; Cy- 
ринов Даниил Владимирович, ORCID: 0000-0001-5822-8575, Ханты-Мансийская государственная медицинская академия, г. Ханты-Мансийск, Россия, surinof.daniil@yandex.ru.

\section{Introduction}

Students' adaptation to studying at the university has always been challenging. The new social role implies that a student needs to develop new behavioral repertoireand seek opportunities to establish oneself in the new status. This process of gaining a foothold in the unfamiliar environment takes a long time, and it causes students anxiety and stress. Students' activity decreases, and they may fail to adopt new behaviors and perform usual activities [7].

The adaptation process includes biological, social and psychological levels. The biological level is associated with acclimatization or with the genotype and selection of useful traits (distance runner, sprinter). The social level is associated with the socialization and the interiorizationof newgroup norms. The psychological level of adaptation is realized through decision making, manifestations of activity and expected results of actions $[2 ; 5 ; 14]$.

The daily dynamics of human performance israther pronounced. As a rule,humans arehighly capable in the daytime but their performancedeclines at night. At the 'warm-up' phase, the performance is unstable and changes in waves; hence one can observe the instability of work actions and slight increases/decreases in the quantitative and qualitative characteristics of labor productivity. At the phase of sustainable performance, the productivity is stably high. At the phase of decreasing performance (fatigue), there appear tiredness, low motivation, a lack of interest in the current work, disturbance of the general sense of well-being, bad mood, erroneous actions, and the general deterioration of labor productivity [1; $16]$.

Distance learning at the universityis generating considerable interest $[4 ; 9 ; 12]$, and it seems relevant to study the dynamics of mental performance in the absence of a 'master timer', such as a class schedule or a lesson plan, in distance learning. The purpose of this work is to study the time preferences of students performing daily tasks during distance learning and to determine if such preferences depend on sex and the year of study.

\section{Participants, Materials and Procedure}

Male and female students enrolled in the Khanty-Mansiysk State Medical Academy, KhantyMansiysk, Russia, participated in the study. The students could choose the time of study and rest themselves, with no actualclass schedule. The activity of distance learning students in time was investigated. Upon receipt of the students' responses to daily tasks, the time of file arrivalto the professor's computer was recorded.

In total, the arrival time of 1,374 files was analyzed, of which 386 were the completed tasksturned in by young males, and 988 byyoung females. The turned-in tasks belonged to the following courses:

- first-year course of anatomy, 200 by male students, 446 by female students, 646 in total;

- second-year course of normal physiologythe students',43 by male students, 192 by female students, 235 in total;

- third-year course ofoperative surgery, 82 by male students, 185 by female students, 267 in total;

- fifth-year course ofhospital therapy ( 5 and 6 courses), 50 by male students, 104 by female students, 154 in total;

- sixth-year course ofhospital therapy, 11 by male students, 61 by female students, 72 in total;

Thestudents' responsesweredivided by sex and the year of study and entered into the database with time accuracy of one hour. The absolute number of responses was converted into relative indicators for comparison (conventional units). The study continued from 19 March to 30 April 2020.

Wavelet analysis was used to test the hypothesis of multiple cycles [13]. A wavelet is a mathematical function that allows analyzing frequency components of collected data. Signals are analyzed in the plane of wavelet coefficients (scale - time - level). The obtained wavelet spectrograms fundamentally differ from regular Fourier spectra in that they give a clear reference of a signal spectrum to time [6]. In this study, the periods of constant and insertion rhythms, their energy (amplitude) and significance were analyzed.

\section{Results}

First to sixth-yearmedicalstudentsdemonstrated sex differences of a qualitative nature in the daily learning activity (Fig. 1). The observation of the female students' behavior produced a fairly smooth daily 
curve, with a decrease in the nighttime, minimum activity around 7-8 am, a non-steppedincrease in the daytime, and maximum activity from $4 \mathrm{pm}$ to $10 \mathrm{pm}$.

To compare, the male students had periods of activity interrupted by episodes of inactivity. The surges in activity occurred at $11 \mathrm{am}, 1 \mathrm{pm}, 5 \mathrm{pm}, 9 \mathrm{pm}$, and $11 \mathrm{pm}$. It should be noted that there were surges of night activity at $3-4 \mathrm{am}$.

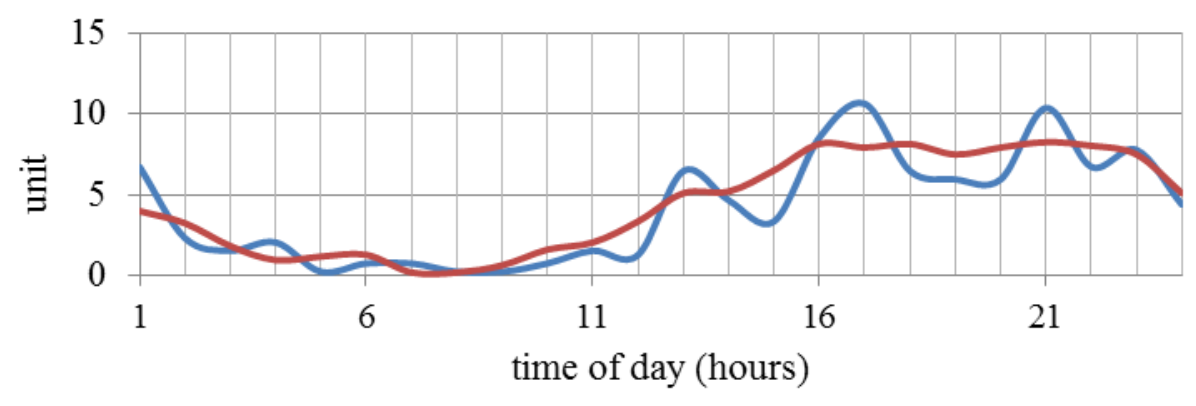

Fig. 1. Daily activity of first to sixth-yearstudents in distance learning: - -male; - -female

The learning activity of junior and senior students by sex is shown in Figure 2 for females and Figure 3 for males. The both senior and junior female students demonstrated a noticeable activity completing educational tasks at night. The juniorfemale students were highly active throughout the day till the evening, while the senior femalestudents most often turned in the completed tasks at $11 \mathrm{am}, 2 \mathrm{pm}, 7 \mathrm{pm}$ and $9 \mathrm{pm}$.

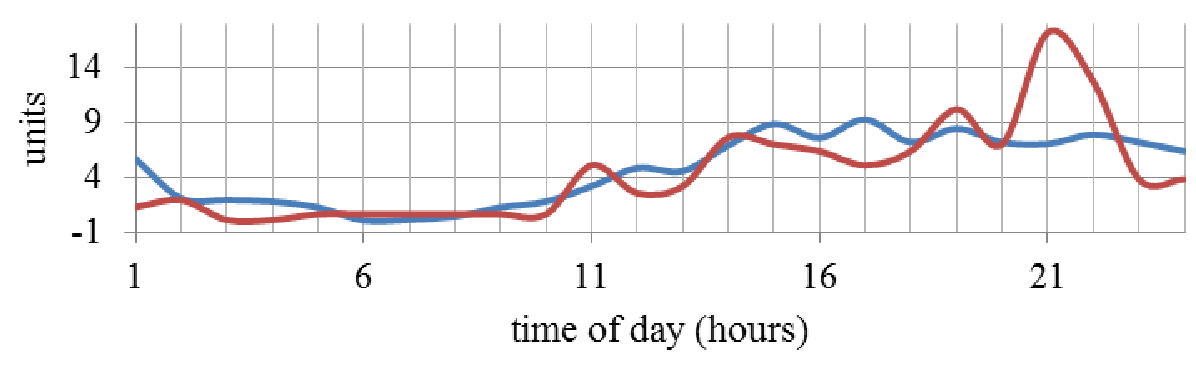

Fig. 2. Daily activity of first to third-yearfemale students and fourth to sixth-year female students in distance learning: - - senior; - - junor

The curveof the educational activity fluctuations in Figure 3 indicates that the senior male students mostly belong to arrhythmic and evening chronotypes. They demonstrated the inactivity in early morning hours, the eagerness to learn awakening around $10 \mathrm{am}$, leisurely work with breaks during the day, and going to bed around $11 \mathrm{pm}$. The junior male students were not synchronized to the day cycle, which was manifested by noticeable night activity and fluctuations in learning activity from 6 am midnight.

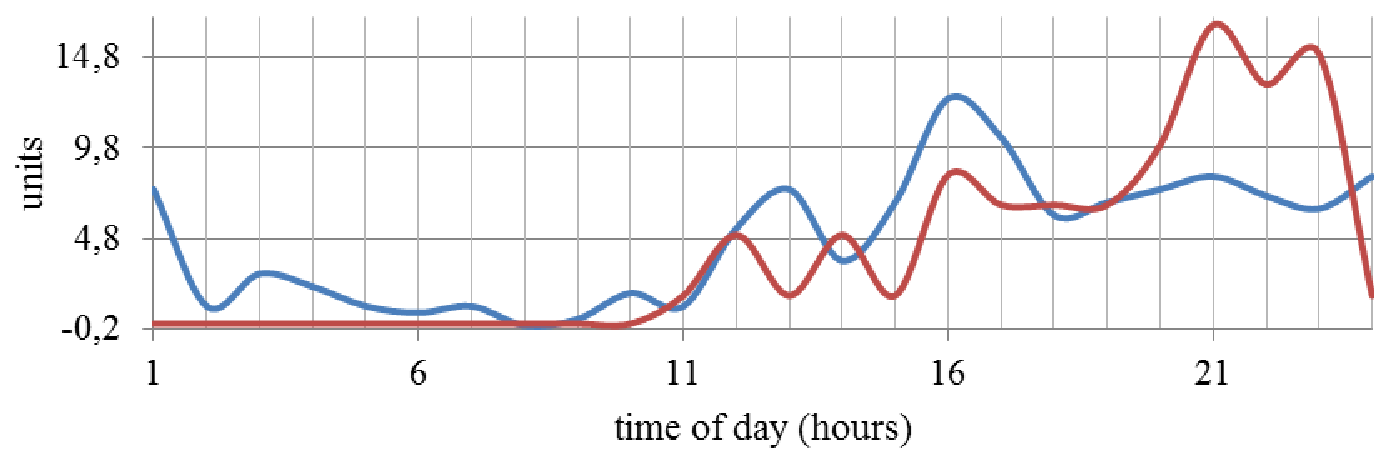

Fig. 3. Daily activity of first to third-year male students and fourth to sixth-year male students

in distance learning: -- senior; -- junor 
The wavelet analysis detectedinsignificant rhythmic fluctuationswith a period of 5.4 hours $(p=0.285)$ for female students and 4.3 hours $(p=0.182)$ for male students. They occurred in the evening hours during the period of high performance.

\section{Discussion}

The ability to maintain physical and mental performance is especially relevant during the period of high information load on students. The typical performance curve (Fig. 4) implies the lowest activity around 3-4 am [8]; the performance progressively increases reaching a maximum at 11 am and isfollowed by a noon abatement; another rise in activityhappens around 8-9 pm followed by a nightdecline.

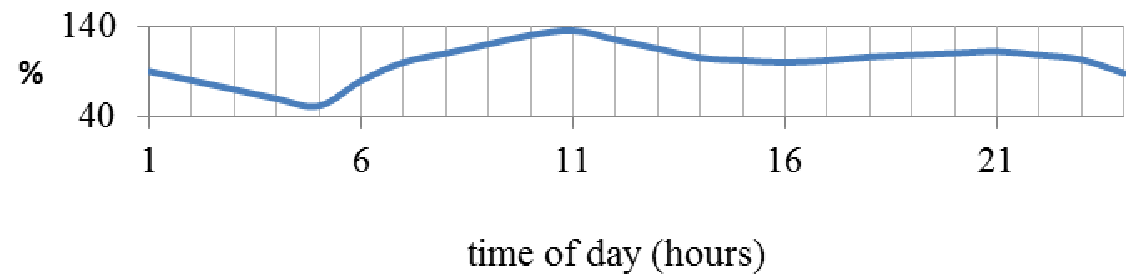

Fig. 4. Daily fluctuations in performance according to Lifanov [8]

The obtained performance curves partially agree with Glybin's [3] hypothesis (Fig. 5), according to which the human performance rhythm is determined by a single wave process with five physiological rises (5 am, $11 \mathrm{an}, 4 \mathrm{pm}, 8 \mathrm{pm}$, and $12 \mathrm{am})$ and the equal number of recessions ( $2 \mathrm{am}, 9 \mathrm{am}, 2 \mathrm{pm}, 6 \mathrm{pm}$, $10 \mathrm{pm}$ hours). The wavelet analysis in this study also indicated the presence of intraday cyclicality with a period of four to six hours.

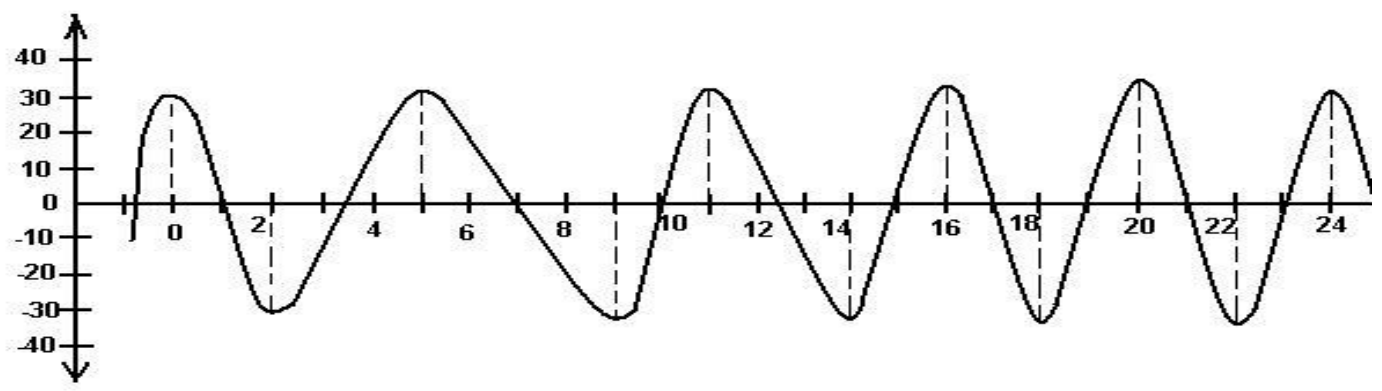

Fig. 5. Daily physiological performance rhythms [3]

In the absence of social regulation, the daytime and nighttime activity of students corresponded to the distribution of chronotypesthat typifies a northern region, with arrhythmic and evening types prevailingbut the morning biorhythmic stereotype having a minimal representation.

\section{Conclusion}

To summarize, with no 'master timer' in distance learning, students demonstrated pronounced sex differences in the daily dynamics of performance. Young femaleshad maximum performance during the day and minimum performance at night, which corresponds to the most common type. Young males were observed to have several ascents in their performance during the 24-hour period. First-year and secondyear students' learning behavior was less synchronized with the day-night cycle. The distribution of activity corresponds to the arrhythmic and evening chronotypes. The wavelet analysis found insignificant four to five hour rhythmic fluctuations that occurred in the evening hours, during the period of students' high educational performance.

\section{REFERENCES}

1. Asilderova, M. M., Agaragimova, V. K., Gasanguseynova, P. A., \& Gasanova, B. M. (2016). Psychological indicators of adaptation of first-year students to training conditions in a higher education institution. The world of science, culture and education, 3(58), 74-76. (In Russian).

2. Vishnevsky, K. S. (2014). Fiziologiya trudovykh protsessov. Moscow. (In Russian).

3. Glybin, L.Ya. (1987). Vnutrisutochnaya tsiklichnost' proyavleniya nekotorykh zabolevanii. Vladivostok. (In Russian).

4. Denisova, T. L. (2013 Pedagogical support of distance training of university students. Vestnik Buryatskogo gosudarstvennogo universiteta, (1), 173-177. (In Russian). 
5. Kozlov, D. V., \& Ponomarev, V. V. (2006). Integrativnye formy povysheniya dvigatel'noi aktivnosti studentov v protsesse fizicheskogo vospitaniya v vuze. Vestnik KGU. Gumanitarnye nauki, (6(2)), 154-159. (In Russian).

6. Kravchenko, V. F., \& Churikov, D. V. (2018). Tsifrovaya obrabotka signalov atomarnymi funktsiyami i veivletami. Moscow. (In Russian).

7. Kuznetsov, A. K. (2013). Dvigatel'naya aktivnost' studentov. In Konstruirovanie cheloveka: materialy XI Vseros. nauch.-prakt. konf. Tomsk. 277-281. (In Russian).

8. Lifanov, E. V. (2006). Fiziologo-gigienicheskie aspekty trudovoi deyatel'nosti cheloveka. Volgograd.

9. Marchuk, N. Yu. (2013). Psychological and pedagogical peculiarities of distance education. Pedagogical Education in Russia, (4).78-85. (In Russian).

10. Molchanova, T. N., Gudkov, A. B., \& Ragozin, O. N. (2009). Dynamics of some psychophysiological parameters discret constitutional types depending on the duration of adapting to the north. Human ecology, (5). 30-33. (In Russian).

11. Molchanova, T. N., \& Ragozina, O. V. (2009). Occurrence discrete types of constitution in genetically untied populations living in northern region. I.P. Pavlov Russian medical biological herald, (1).18-26. (In Russian).

12. Ovcharov, A. V., \& Moskalenko, E. V. (2017). The use of e-learning and distance learning technologies in higher educational institutions of the Altai Krai on the example of the Altai State Pedagogical University The world of science, culture and education, 4(65), 88-92. (In Russian).

13. Ragozin, O. N., Bochkarev, M. V., Kosarev, A. N., Kot, T. L., \& Tatarintsev, P. B. (2014). Programma "Issledovanie biologicheskikh ritmov metodom veivlet-analiza". Sv-vo o gos. registratsii programmy dlya EVM №2014611398, data registratsii 03.022014 g. (In Russian).

14. Sadvakassova, N. A. (2018). Problem of mental workability in children. Scientific Review. Basic and applied research, (3). (In Russian). http://www.scientificreview.ru/ru/article/view?id=38

15. Shalamova, E. Yu., Safonova, V. R., Bochkarev, M. V., \& Kuz'menko, I. O. (2012). Effect of photoperiod on the performance of students - representatives of different chronotype. RUDN Journal of Medicine, (S7), 225226. (In Russian).

16. Shemetova, E. G., \& Malgin, E. L. (2017). Dynamics of students' performance capability in the learning process. Philological Sciences. Issues of Theory and Practice, 2(68). 215-218. (In Russian).

\section{ЛИТЕРАТУРА}

1. Асильдерова М. М., Агарагимова В. К., Гасангусейнова П. А., Гасанова Б. М. Психологические показатели адаптации студента-первокурсника к условиям обучения в вузе // Мир науки, культуры, образования. 2016. № 3(58) С. 74-76.

2. Вишневский К. С. Физиология трудовых процессов. М.: Владос, 2014. 321 с.

3. Глыбин Л. Я. Внутрисуточная цикличность проявления некоторых заболеваний. Владивосток, 1987.

4. Денисова Т. Л. Педагогическое сопровождение дистанционного обучения студентов вуза // Вестник Бурятского государственного университета. Педагогика. Филология. Философия. 2013. № 1. С. $173-177$.

5. Козлов Д. В., Пономарев В. В. Интегративные формы повышения двигательной активности студентов в процессе физического воспитания в вузе // Вестник КГУ. Гуманитарные науки. 2006. №. 6(2). С. 154159.

6. Кравченко В.Ф., Чуриков Д.В. Цифровая обработка сигналов атомарными функциями и вейвлетами. Москва: Техносфера. 2018. 182 с.

7. Кузнецов А. К. Двигательная активность студентов // Конструирование человека: материалы ХІ Всерос. науч.-практ. конф. Томск: Изд-во ТГПУ. 2013. С. 277-281.

8. Лифанов Е. В. Физиолого-гигиенические аспекты трудовой деятельности человека. Волгоград, $2006.85 \mathrm{c}$.

9. Марчук Н. Ю. Психолого-педагогические особенности дистанционного обучения // Педагогическое образование в России. 2013. № 4. С. 78-85.

10. Молчанова Т. Н., Гудков А. Б., Рагозин О. Н. Динамика некоторых психофизиологических параметров у представителей частных конституциональных типов в зависимости от длительности адаптации к условиям Севера // Экология человека. 2009. № 5. С. 30-33.

11. Молчанова Т. Н., Рагозина О. В. Встречаемость дискретных конституциональных типов в генетически несвязанных популяциях, проживающих в северном регионе // Российский медико-биологический вестник имени академика ИП Павлова. 2009. № 1. С. 18-26.

12. Овчаров А. В., Москаленко Е. В. Использование электронного обучения и дистанционных образовательных технологий в высших учебных заведениях алтайского края на примере Алтайского государственного педагогического университета // Мир науки, культуры, образования. 2017. № 4 (65). С. 88-92. 
13. Рагозин О. Н., Бочкарев М. В., Косарев А. Н., Кот Т. Л., Татаринцев П. Б. Программа «Исследование биологических ритмов методом вейвлет-анализа». Св-во о гос. регистрации программы для ЭВМ № 2014611398, дата регистрации 03.022014 г.

14. Садвакасова Н. А. Проблема умственной работоспособности у детей // Научное обозрение. Фундаментальные и прикладные исследования. 2018. № 3. http://www.scientificreview.ru/ru/article/view?id=38

15. Шаламова Е. Ю., Сафонова В. Р., Бочкарев М. В., Кузьменко И. О. Влияние продолжительности светового дня на работоспособность студенток - представительниц разных хронотипов // Вестник Российского университета дружбы народов. Серия: медицина. 2012. № S7. С. 225-226.

16. Шеметова Е. Г., Мальгин Е. Л. Динамика работоспособности студентов вуза в процессе обучения // Филологические науки. Вопросы теории и практики. 2017. № 2(68). С. 215-218.

Ragozin O. N., Shalamova Ye. Yu., Ilyushchenko N. A., Ragozina O. V., Shevnin I. A., Surinov D. V. Sex and age characteristics of daily activity of distance learning students in northern climate // Вестник Нижневартовского государственного университета. 2020. № 2. С. 130-135. https://doi.org/10.36906/2311-4444/20-2/17

Ragozin, O. N., Shalamova, Ye. Yu., Ilyushchenko, N. A., Ragozina, O. V., Shevnin, I. A., \& Surinov, D. V. (2020). Sex and age characteristics of daily activity of distance learning students in northern climate. Bulletin of Nizhnevartovsk State University, (2). 130-135. https://doi.org/10.36906/2311-4444/20-2/17 